\title{
Appendix 4 Persilschein
}

For his honor Nándor Szamocseta, Budapest VI. Csengery Street $62 .{ }^{421}$

Events fade with time. In order to save them for posterity we will put down those happenings of the last several months during which You aided us, and we hereby express our sincere and deepest gratitude for your help.

On the year's October 16 Arrow Cross men armed with hand grenades came to Csengery Street 64. Your aunt Mrs Strucky called for You and You personally prevented that the Arrow Cross would access the air raid cellar where approx. 70 Jewish people were hiding.

The following day Arrow Cross and Death Skull soldiers came to the house and You again stopped them before they reached the shelter because You personally assured their leader that there were no Jews in the cellar.

On the night of October 18 German soldiers came to the house. Once again You prevented their ascending into the apartments with what you prevented further atrocities.

Besides these actions there were countless instances when You demonstrated that You are a true, sympathetic, helping friend of the house's tenants.

Budapest, January 20, 1945

Özv. Horschawsky Sándorné

Singer Gáborné

Özv. Szegő Albertné

Szegő Ármin

Gábor Ervin

Özv. Lichter Izraelné

Róth József

Biró Dénesné

R. Pauncz Erzsébet

Özv. Ippi Bydeskuti Aladárné

Özv. Hidvéger Miklosné

Özv. Weisz Andorné

Pauner Ferencné

Dr. Popper Lászlóné

421 BFL 19273/1949. 279. transcript of the handwritten text. 
Klein Ernő

Klein Ernőné

Klein Ibolya [These three with the same handwriting.]

Spitzer Ernőné

Várnai L. Istvánné

Glückkron Ernőné. 